\title{
Effects of Supplementation on Juniper Intake by Goats
}

\author{
Erika S. Campbell, ${ }^{1}$ Charles A. Taylor, ${ }^{2}$ John W. Walker, ${ }^{3}$ Christopher J. Lupton, ${ }^{4}$ \\ Dan F. Waldron, ${ }^{4}$ and S. Y. Landau ${ }^{5}$
}

\begin{abstract}
Authors are ${ }^{1}$ Post Doctoral Research Associate and ${ }^{2}$ Professor, Texas A\&M University Agricultural Experiment Station, Sonora, TX 76950 ;
${ }^{3}$ Resident Director and ${ }^{4}$ Professor, Texas Agricultural Experiment Station, Texas A\&M University Agricultural Research and Extension Center, San Angelo, TX 76901; and ${ }^{5}$ Professor, Department of Natural Resources and Agronomy, Institute of Plant Science, Agricultural Research Organization, the Volcani Center, Bet Dagan, Israel 50250.
\end{abstract}

\begin{abstract}
The potential for winter supplementation to increase juniper intake by goats on rangelands in the Edwards Plateau region of Texas was assessed in two experiments. The first experiment evaluated the effect on juniper intake of either no supplementation (negative control) or supplementation with corn, alfalfa, or cottonseed meal fed at an isonitrogenous protein level of $1.5 \mathrm{~g} \cdot \mathrm{kg}$ body weight ${ }^{-1}$ for 12 days. Redberry juniper (Juniperus pinchotii Sudw.) consumption by individually penned Spanish, Boer $\times$ Spanish, Spanish $\times$ Angora, and Angora goats was measured on days 11 and 12. Each goat received each supplement in a complete $4 \times 4$ Latin square design. Juniper intake increased for goats supplemented with alfalfa and cottonseed meal $(P=0.001)$, but not for those supplemented with corn $(P=0.944)$. Boer $\times$ Spanish goats did not differ in levels of consumption $(P=0.085)$ from the other breeds. A second study investigated the effect of either no supplementation or soybean meal supplementation on juniper consumption by free grazing Angora and Boer $\times$ Spanish goats. Forty goats were assigned to four pasture groups by breed and previous juniper intake, and randomly allocated to either the treatment (supplementation) or control (no supplementation) regime in a complete block design. After 4 days of grazing and supplementation, fecal samples were collected to estimate percent of juniper in the diet using near-infrared spectroscopy. Goats were then rotated to another pasture. Juniper intake was highest for goats supplemented with soybean meal $(P=0.034)$. Breed of goat did not affect intake $(P=0.240)$. Goats previously categorized as high juniper consumers based upon prior measurements of juniper intake ate more juniper $(P=0.003)$ than those classified as low consumers. This research indicates that the effectiveness of goats for biological control of juniper can be improved with a high protein, low starch supplement.
\end{abstract}

\section{Resumen}

En dos experimentos se evaluó el potencial de la suplementación invernal para incrementar el consumo de "Juniper" por las cabras en los pastizales de la Meseta Eduardo, Texas. El primer experimento evaluó el efecto de la suplementación con maíz, alfalfa, o pasta de semilla de algodón alimentadas a un nivel isoproteico de $1.5 \mathrm{~g} \cdot \mathrm{kg} \mathrm{PV}^{-1}$ por 12 días sobre el consumo de "Juniper," y se comparó con animales no suplementados (control negativo, NC). En los días 11 y 12 se midió el consumo individual de Redberry juniper (Juniperus pinchotii Sudw.) de cabras Españolas, Boer $\times$ Española y Española $\times$ Angora encerradas individualmente en corrales. Cada cabra recibió cada uno de los suplementos en un diseño de Cuadro Latino completo $4 \times 4$. El consumo de "Juniper" aumentó en las cabras suplementadas con alfalfa y pasta de semilla de algodón $(P=0.001)$, pero no en las que recibieron maíz $(P=0.944)$. Las cabras Boer $\times$ Española no difirieron de las otras razas en los niveles de consumo $(P=0.944)$. En un segundo estudio investigó le efecto de suplementar o no con pasta de soya sobre el consumo de "Juniper" de cabras Angora y Boer $\times$ Española en libre pastoreo. Cuarenta cabras se asignaron a cuatro grupos de acuerdo a su raza y consumo previo de "Juniper" y se asignaron aleatoriamente al tratamiento (suplementación) o al control (sin suplementación) en un diseño de bloques completos. Después de 4 días de apacentamiento y suplementación, se colectaron muestras fecales para estimar el porcentaje de "Juniper" en la dieta usando espectroscopia de reflectancia cercana al infrarrojo (NIRS fecal), después las cabras fueron rotadas a otro potrero. El consumo de "Juniper" fue mayor para las cabras suplementadas con pastas de soya $(P=0.034)$ y la raza no afectó el consumo $(P=0.240)$. Las cabras previamente catalogadas (en base a medidas anteriores de consumo de "Juniper") como altas consumidoras de "Juniper" consumieron más de esta especie $(P=0.003)$ que las clasificadas como bajas consumidoras. Esta investigación indica que la efectividad de las cabras para controlar biológicamente el "Juniper" puede ser mejorada con una suplementación alta en proteína y baja en almidón.

Key Words: detoxification, Juniperus, monoterpenes, prescribed herbivory

This research was supported by Research Grant Award IS-3555-04 from BARD, The United States-Israel Binational Agricultural Research and Development Fund and Texas Food and Fibers Commission Project No. FF-b-06-02.

Correspondence: Erika Campbell, Texas Agricultural Experiment Station, 395 ECR/PO Box 918, Sonora, TX 76950. Email: ejcampbell@ag.tamu.edu

Manuscript received 24 October 2006; manuscript accepted 19 July 2007.

\section{INTRODUCTION}

Juniper infestation of Texas rangelands is an important dilemma because of its impact on livestock production (Taylor and Ralphs 1992), water availability and quality (Hester et al. 1997), wildlife habitat, and volatile fuels fire hazard (Taylor 
2006). Juniper species, once minor proportions of the rangeland flora, have expanded their range. Ashe juniper (Juniperus ashei Buch.) and redberry juniper (Juniperus pinchotii Sudw.) now occupy most soil types and vegetation communities in central and western Texas. Because carrying capacity can be reduced by as much as $85 \%$ in the transition from grassland to a closed canopy cover of juniper (Ueckert et al. 1994), some form of juniper management is essential for maintaining rangeland productivity.

Chemical and mechanical control methods are effective but can be cost prohibitive (Whitson et al. 1984; Lee et al. 2001). Also there are real or perceived environmental concerns regarding the use of chemicals (Ralphs and Busby 1979; Johnson 1980; Bovey and Richardson 1991) and mechanical treatments (Wright et al. 1976) for juniper management, especially on rangeland watershed quality. Fire also is an effective juniper management tool (Steuter and Britton 1983; Ueckert et al. 2001) but may not be practical for every situation.

Goats have the potential to provide a cost-effective and herbicide-free tactic to manage juniper. Goats are evolutionarily programmed through morphophysiological and behavioral adaptations to consume browse (Hoffmann 1973). Observational data suggest that juniper intake typically ranges from $0 \%-13 \%$ when goats are foraging on pasture (Bryant et al. 1979; Warren et al. 1981; Warren et al. 1984). Researchers using pen studies measuring juniper intake by Angora and Spanish goats have reported maximum intake values of 33.5\% $\left(6.7 \mathrm{~g} \cdot \mathrm{kg}\right.$ body weight ${ }^{-1}$ [BW]) of diet composition (Pritz et al. 1997). Even though juniper species can represent an important part of goat's diets, the overall intake of juniper tends to be self limited when juniper consumption is higher than $30 \%$ of the diet (Pritz et al. 1997; Bisson et al. 2001; Straka et al. 2004). The restriction in juniper intake appears to be an attempt to regulate consumption of monoterpenes and avoid negative postingestive consequences of monoterpene exposure at higher levels. Toxic monoterpenes in juniper deter goat browsing of juniper plants by reducing nutrient assimilation (Riddle et al. 1999), and (or) by imposing high detoxification costs postabsorption (Freeland and Janzen 1974).

We hypothesized that the additional protein provided to goats by winter supplementation strategies would enhance the metabolism of secondary compounds by providing precursors or additional energy required for degrading the secondary compounds, thus increasing the consumption of juniper. We also were interested in a concurrent comparative evaluation of the supplements provided. At an isonitrogenous level, would the other nutritional components of the feed (i.e., degradable protein, digestible energy) influence their efficacy? Although researchers using pen studies with other species of animals have investigated the effect of protein or energy supplementation in reducing toxicity and increasing consumption of plants that have high levels of terpenoids, results have been equivocal. Burritt et al. (2000) reported that protein and energy supplementation did not increase intake of sagebrush by lambs. Villalba et al. (2002), however, reported that sagebrush intake was higher for lambs and kid goats fed a high protein supplement. In a subsequent study, energy and protein concentrations influenced the amount of terpenes ingested by lambs (Villalba and Provenza 2005).

A second promising area of study is the identification and exploitation of individual animal and breed differences in juniper preference to increase effectiveness of vegetation management. Individual animal variation in juniper preference is evident (Riddle et al. 1996) and is also seen in studies evaluating intake of other chemically defended plant species such as blackbrush (Coleogyne ramosissima Torr.; Provenza et al. 1990) and sagebrush (Artemisia tridentata Nutt.; Snowder et al. 2001). Goat breeds vary in their preference for juniper with higher levels of consumption reported for Spanish or Spanish $\times$ Boer goats than fiber-producing Angora goats (Warren et al. 1984; Pritz et al. 1997). The influence of animal and breed preference for juniper might influence their response to a supplementation program.

The objective of these two experiments was to determine the effects of supplementation on juniper consumption by goats. Experiment 1 compared the effects of three commonly used winter feed supplements on juniper consumption by two breeds and two crossbreeds of goats. Experiment 2 evaluated the influence of breed of goat, previously measured propensity for juniper, and protein supplement on juniper intake.

\section{METHODS}

\section{Study Site}

The study site for both experiments was the Texas A\&M University Agricultural Experiment Station at Sonora (lat $30^{\circ} 15^{\prime} \mathrm{N}$, long $100^{\circ} 33^{\prime} \mathrm{W}$ ) located in the western Edwards Plateau region of Texas. The research station consists of approximately 1458 ha of rangeland composed of mixtures of grasses, forbs, and woody species. Average growing season is 240 days and the elevation is about $632 \mathrm{~m}$. Precipitation is highly variable. Consequently, frequent droughts and occasional wet years are the norm. Growing season precipitation averaged $409 \mathrm{~mm}$ from 1919 to 1989 (Taylor et al. 1993).

The most common soils on the station are Tarrant silty clay and Tarrant stony clay (members of the clayey-skeletal, montmorillonitic, thermic family of Lethic Haplustalls, with some Kavett silty clay soils in low-lying areas; Taylor et al. 1993). The Tarrant stony clays are the dominant soils, which overlay a fractured limestone substrate, and are generally 15$30 \mathrm{~cm}$ deep. These soils contain $5 \%$ to $70 \%$ limestone fragments or slabs of limestone outcroppings. The topography is typified by rolling, stony hills with slopes of $3 \%-4 \%$, which produce patterns of shallow divides, limestone outcrops, and low lying areas of deeper soils (USDA-SCS 1972).

\section{Experiment 1-Pen Trial}

Experiment 1 was designed to compare the effects of three isonitrogenous supplemental protein sources on juniper intake. The protein sources selected for this study reflected three winter supplements commonly used to correct seasonal forage nutrient deficiencies. Feeding rates were compatible with recommended supplementation levels for goats on winter rangelands (Huston et al. 1971). Feed treatments included a negative control (NC, no supplemental feed), corn (C), alfalfa (A), and cottonseed meal (CSM). At the target rate, all animals were fed crude protein $(\mathrm{CP})$ to provide $0.24 \mathrm{~g} \mathrm{~N} \cdot \mathrm{kg} \mathrm{BW}^{-1}$ (Table 1), $100 \%$ of their maintenance protein requirements (NRC 1981).

Two breeds and two crossbreeds of goats received four feed treatments in a complete $4 \times 4$ Latin square design with four 
Table 1. Crude protein (CP), degradable protein, and digestible energy contents of supplemental feed treatments offered to goats with ad libitum access to redberry juniper. $\mathrm{DM}=$ dry matter.

\begin{tabular}{lccccc}
\hline & \multicolumn{5}{c}{ Nutrient contents (DM basis) } \\
\cline { 2 - 6 } & $\% \mathrm{CP}$ & $\begin{array}{c}\text { Degradable protein } \\
\% \text { of CP }\end{array}$ & $\begin{array}{c}\text { Digestible energy } \\
\left(\text { Mcal } \cdot \mathrm{kg}^{-1}\right)\end{array}$ & $\begin{array}{c}\text { Correction ratio } \\
\text { for equal CP }\end{array}$ & $\begin{array}{c}\text { Amount fed } \\
\left.(\mathrm{g} \cdot \mathrm{kg} \mathrm{BW})^{-1}\right)\end{array}$ \\
\hline Alfalfa & 15 & 61.4 & 2.3 & 1.00 & 10.0 \\
Corn & 9 & 31.3 & 3.4 & 1.67 & 16.7 \\
Cottonseed meal & 42 & 52.1 & 3.0 & 0.36 & 3.7 \\
\hline
\end{tabular}

${ }^{1}$ Source for reference value for degradable protein was Dairy One (2006) Forage Lab Feed Composition Library (values not reported in NRC, 1981).

replications per treatment. Goat breeds, four animals per breed, were Angora (28.6 $\pm 3.4 \mathrm{~kg} \mathrm{BW})$, Spanish (33.3 $\pm 5.3 \mathrm{~kg} \mathrm{BW})$, Angora $\times$ Spanish $(29.7 \pm 2.4 \mathrm{~kg}$ BW), and Spanish $\times$ Boer $(37.0 \pm 6.8 \mathrm{~kg} \mathrm{BW})$ for a total of 16 mature $(>2$ years old) nannies. Animals were individually fed and received all four treatments. The Spanish $\times$ Boer goats were larger animals, due to the Boer influence; therefore intake is reported on a $\mathrm{g} \cdot \mathrm{kg}$ $\mathrm{BW}^{-1}$ basis to account for this difference.

Each trial was 12 days long, with the first 10 days representing a preconditioning period. Each day of the trial, supplemental feed treatments were offered individually from 0800 to 1200 hours. Refusals were collected and weighed, and intake of supplemental feed calculated. Nutrient values for supplements and juniper were calculated using reference values (NRC 1981; Huston et al. 1981; Dairy One 2006).

Fresh juniper foliage was harvested daily at 0800 from a 61ha pasture. One redberry juniper tree per day was randomly selected to provide juniper to all goats for the day's feeding period. From 0900 to 1400 hours, goats were offered redberry juniper ad libitum by attaching branches in an upright position in each pen. Branches of juniper offered as feed were weighed before and after each feeding period. Corrections for moisture loss were made by weighing branches similar to the ones offered but not grazed at the same time as the grazed branches. Juniper intake was determined by averaging consumption on days 11 and 12 and calculated on a $\mathrm{g} \cdot \mathrm{kg} \mathrm{BW}^{-1}$ basis.

Statistical Analyses. Independent variables were breed type (Spanish, Angora, Spanish $\times$ Angora, Spanish $\times$ Boer $)$, and treatment (control, corn, alfalfa, and cottonseed meal). Juniper intake, expressed on a $\mathrm{g} \cdot \mathrm{kg} \mathrm{BW}^{-1}$ basis, was the dependent variable. Goats were fed individually and considered replicates. Analysis of variance was conducted using PROC GLM (SAS 2002). Interactions were tested and found not to be significant, so a reduced model was used that included only main effects. Orthogonal contrasts of treatment effects for juniper intake, nutrient content of juniper, and total nutrient content of diet ingested were as follows: 1) $\mathrm{NC}$ vs. C, A, CSM; 2) C vs. A, CSM; and 3) NC, C vs. A, CSM. Orthogonal contrasts for comparisons of nutrient content of the supplements were as follows: 1) C vs. A and CSM, and 2) A vs. CSM. Mean separation of other main effects was determined using protected $(P<0.05)$ least significant differences. The data are presented as least squares means.

\section{Experiment 2-Grazing Trial}

The effects of a soybean meal (SBM) supplement, goat breed, and propensity to graze juniper, on juniper intake by freegrazing goats was investigated during a 16-day period in midwinter. Soybean meal was used instead of cottonseed meal to prevent another secondary metabolite, gossypol, from possibly interacting with other allelochemicals and affecting consumption of juniper. Goats were selected to represent high and low juniper intake. Classification of goats was based on genetic merit for percentage juniper in the diet, which was estimated using a separate animal model for each breed (Walker et al. 2007). The Angora predictions used 778 records from 577 goats and the meat goat predictions used 239 records from 176 goats. Percentage juniper in the diet of goats for calculating genetic merit was estimated using near-infrared spectroscopy (NIRS) predictions of fecal samples collected when they were free-grazing on juniper-infested pastures. The range of juniper in the diet for the high groups was $24 \%$ to $41 \%$ and the low group $0 \%$ to $20 \%$.

Immediately prior to initiation of this experiment, the goats were grazed on an 8-ha, juniper-free enclosure for 10 days and fecal samples were collected on the last day of that period to provide fecal material devoid of juniper to aid in fecal NIRS calibration.

Goats were then preconditioned to juniper by grazing on a 16-ha, juniper-infested pasture for a period exceeding 10 days before separating them into four treatment pastures. Ten goats were assigned to each pasture by breed and intake group as follows: pasture 1, high Angora; pasture 2, low Angora; pasture 3 , high Boer $\times$ Spanish; pasture 4 , low Boer $\times$ Spanish. Animals within pasture group were allocated randomly to either the treatment (supplementation) or control (no supplementation) regime. The 10 goats in each breed or consumer group were rotated between pastures to reduce pasture bias. Each group grazed each pasture for 4 days.

Goats within a pasture grazed freely together but received their supplementation treatment individually. For supplementation, goats were herded to a collection area and placed in individual stalls at 1000 hours for a 3-hour period and then released back to the pasture. Stalls were $0.6 \times 1.8 \mathrm{~m}$, constructed from welded wire panels. Soybean meal $(47.5 \% \mathrm{CP})$ was fed to half the animals at a rate of $0.33 \% \mathrm{BW} \cdot \mathrm{day}^{-1}$. Unsupplemented animals remained penned for this period as well. The supplemental feeding rate was calculated to provide $0.24 \mathrm{~g} \mathrm{~N} \mathrm{~kg} \mathrm{BW}{ }^{-1}$, which is equivalent to the level of nitrogen supplement in Experiment 1. Feed was weighed for each individual animal and any orts remaining after the feeding period were also weighed so that reported feed intake could be adjusted to take refusals into account.

After four days in a pasture, fecal samples for NIRS estimation of percentage juniper in the diet were collected manually at 1600 hours using a 20-mm-wide and 200-mm-long speculum (Total Reproduction, North Ryde, New South Wales, Australia). 
Previous research (Whitworth 2002) indicates that a 4-day period is required for fecal spectra to adequately represent botanical composition of the diet (i.e., supplement treatment). Twenty pellets from each goat were collected for the fecal sample. Sampling was repeated in this manner after 4 days in each new pasture.

Laboratory Analysis. Fecal samples were dried in a forced air oven at $55^{\circ} \mathrm{C}$ for 12 hours, ground in a cyclone mill to pass through a $1 \mathrm{~mm}$ screen, and conditioned for 24 hours in an environment with constant temperature and humidity $\left(21^{\circ} \mathrm{C}\right.$ and $65 \%$, respectively). Samples were then packed into sample cells with a near-infrared transparent quartz cover glass. Cells were scanned 32 times using a Foss scanning reflectance monochromator (model 6500, NIRSystems, Inc., Silver Springs, MD). Reflected energy $(\log 1 / \mathrm{R})$ was measured and averaged over the 32 scans and recorded at 2-nm intervals from 1100 to $2500 \mathrm{~nm}$.

Percentage juniper in the diet was estimated with a previously developed modified partial least squares calibration equation (Whitworth 2002; Walker et al. 2007). The calibration data were from feeding trials conducted in 1999 and 2002 that used diets with known percentages of juniper and a variety of background forages (Whitworth 2002), plus feces collected in 2003 and 2004 from goats grazing rangeland areas similar to the study pastures in this study from which all juniper had been removed (i.e., these represented diets with $0 \%$ juniper). This equation has an $R^{2}=0.88$ and a standard error of cross validation of 6.4 percentage units (Walker et al. 2007). When this equation was used to predict diets from an independent feeding trial with known levels of juniper, treatment differences were readily detected and were similar to actual difference in levels of juniper fed (Walker et al. 2007).

Statistical Analysis. Independent variables were breed (Angora and Boer $\times$ Spanish), previous juniper consumption category (high and low), supplementation (soybean meal and control), and pasture (1, 2, 3, and 4). The dependent variable was percent dietary juniper and the error term was goat within supplement $\times$ breed $\times$ category. Animals were sampled individually and considered replicates. Analyses of variance were conducted using PROC MIXED (SAS 2002). Experiment 2 was a randomized complete block design with supplement, breed, and juniper consumption category as fixed treatment effects and pasture and date as blocking effects. Goats were fed and sampled individually and represented the experimental unit. Study animals consisted of 20 adult Angora nannies $\left(33.2 \pm 5.8 \mathrm{~g} \cdot \mathrm{kg} \mathrm{BW}^{-1}\right.$, mean $\left.\pm \mathrm{SD}\right)$ and 20 adult Boer $\times$ Spanish nannies $\left(55.4 \pm 7.2 \mathrm{~g} \cdot \mathrm{kg} \mathrm{BW}{ }^{-1}\right)$ originating from two populations of goats with either high or low estimated juniper intake (Walker et al. 2007). All interactions were tested and those found not to be significant $(P>0.050)$ were dropped from the model. Means for each effect were compared using the ESTIMATE (SAS 2002) statement. Multiple means comparisons of category $\times$ supplementation treatment groups were performed using the LSMEANS (SAS 2002) statement.

\section{RESULTS}

\section{Experiment 1-Pen Trial}

Results did not vary by trial $(P=0.819)$, indicating that previous treatment did not exert a carry-over effect (Table 2).
Table 2. Summary of $4 \times 4$ Latin square ANOVA to response variable $\mathrm{g} \cdot \mathrm{kg} \mathrm{BW}^{-1}$ juniper consumption. Degrees of freedom (df), $F$ values, and $P$ values are shown. Bold values indicates $P$ value $<0.05$ and italicized value indicates $P$ value $>0.05$ and $<0.10$.

\begin{tabular}{llllll}
\hline & \multicolumn{5}{c}{ Source of variation } \\
\cline { 2 - 6 } \multicolumn{1}{c}{ Response variable } & & $\begin{array}{c}\text { Goat } \\
\text { (breed) }\end{array}$ & Trial & Breed & Treatment \\
\hline Juniper intake $\left(\mathrm{g} \cdot \mathrm{kg} \mathrm{BW}^{-1}\right)$ & df & 12 & 3 & 3 & 3 \\
& $F$ & 4.08 & 0.31 & 2.36 & 4.88 \\
& $P$ & $\mathbf{0 . 0 0 0 3}$ & 0.8186 & 0.0850 & $\mathbf{0 . 0 0 5 3}$ \\
\hline
\end{tabular}

Individual goats within breed varied in juniper intake $(P<0.001)$ but intake by breed did not differ $(P=0.085)$. Spanish $\times$ Boer, Angora, Angora $\times$ Spanish, and Spanish goats consumed $11.95 \pm 10.16, \quad 10.39 \pm 4.66,6.52 \pm 5.46$, and $6.39 \pm 3.77 \mathrm{~g} \cdot \mathrm{kg} \mathrm{BW}^{-1}$ of juniper, respectively.

Supplement treatment affected juniper intake $(P=0.005$, Table 2). Alfalfa and cottonseed meal increased juniper intake compared to control and corn supplementation diets $(P=0.001$, Table 3$)$. There was no difference in juniper intake between the negative control and corn $(P=0.944)$. Because of feed refusals, intake levels for the supplements were different from target values; however, intakes of $\mathrm{CP}$ were not different $(P=0.075)$ among the supplemented groups (Table 3$)$. Intake of digestible energy (DE) was higher for the corn treatment than for alfalfa and cottonseed meal $(P<0.001)$, and there was no difference between alfalfa and cottonseed meal for DE intake. Intake of degradable protein (DP) was lower for the corn treatment compared to alfalfa and cottonseed meal $(P=0.002)$, with no difference between the latter two treatments $(P=0.573)$.

\section{Experiment 2-Grazing Trial}

Juniper intake by goats on pasture was increased 4.6 percentage units $(P=0.03)$ by soybean meal supplementation (Table 4). These results support the data from Experiment 1 in which protein supplementation also increased juniper intake.

Goats classified as high consumers ate more juniper (6.7 percentage units; $P=0.003$ ) than low consumers. Difference in juniper intake between high and low consumers was slightly greater than differences in juniper intake between supplemented and control groups. Breed of goat did not affect intake $(P=0.24)$. There were no interactions between supplementation and category of goat or breed of goat $(P \geq 0.10)$. The highest level of intake was by supplemented high consumers $(31.44 \pm 2.65 \%$ of diet), followed by unsupplemented high consumers $(26.84 \pm 2.77)$, supplemented low consumers $(24.73 \pm 2.47)$ and unsupplemented low consumers $(20.09 \pm 2.48)$.

\section{DISCUSSION}

\section{Protein}

This study showed that protein supplements increased juniper consumption by goats. Previous studies evaluated supplementation of sheep and found similar results, where intake of big sagebrush, another monoterpene-defended plant, was higher 
Table 3. Effects of supplemental feed on intakes of juniper, crude protein (CP), degradable protein (DP), and digestible energy (DE) in the diets of goats in a pen study.

\begin{tabular}{|c|c|c|c|c|c|c|c|c|}
\hline & \multirow{2}{*}{$\begin{array}{c}\text { Negative } \\
\text { control }\end{array}$} & \multicolumn{3}{|c|}{ Supplement } & \multirow[b]{2}{*}{ SE } & \multicolumn{3}{|c|}{ Probability $^{1,2}$} \\
\hline & & Corn & Alfalfa & Cottonseed meal & & 1 & 2 & 3 \\
\hline No. of goats & 4 & 4 & 4 & 4 & - & - & - & - \\
\hline Juniper intake $\left(\mathrm{g} \cdot \mathrm{kg} \mathrm{BW}^{-1}\right)$ & 6.396 & 6.523 & 10.397 & 11.953 & 1.265 & 0.03 & 0.004 & 0.001 \\
\hline \multicolumn{9}{|l|}{$\mathrm{CP}\left(\mathrm{g} \cdot \mathrm{kg} \mathrm{BW}{ }^{-1}\right)$} \\
\hline Supplement & - & 1.416 & 1.166 & 1.473 & 0.097 & - & 0.424 & 0.033 \\
\hline Juniper & 0.418 & 0.424 & 0.676 & 0.777 & 0.082 & 0.035 & 0.004 & 0.001 \\
\hline Total & 0.418 & 1.840 & 1.841 & 2.250 & 0.123 & 0.000 & 0.180 & 0.001 \\
\hline \multicolumn{9}{|l|}{$\mathrm{DP}\left(\mathrm{g} \cdot \mathrm{kg} \mathrm{BW} \mathrm{W}^{-1}\right)$} \\
\hline Supplement & - & 1.093 & 0.824 & 0.766 & 0.065 & - & 0.002 & 0.573 \\
\hline Juniper & 0.121 & 0.123 & 0.196 & 0.225 & 0.024 & 0.035 & 0.004 & 0.006 \\
\hline Total & 0.121 & 1.216 & 1.020 & 0.991 & 0.070 & 0.000 & 0.018 & 0.000 \\
\hline \multicolumn{9}{|l|}{$\mathrm{DE}\left(\right.$ Mcal $\left.\cdot \mathrm{kg} \mathrm{BW}^{-1}\right)$} \\
\hline Supplement & - & 0.047 & 0.019 & 0.011 & 0.003 & - & 0.000 & 0.080 \\
\hline Juniper & 0.017 & 0.017 & 0.028 & 0.032 & 0.003 & 0.033 & 0.004 & 0.001 \\
\hline Total & 0.017 & 0.064 & 0.046 & 0.043 & 0.004 & 0.001 & 0.001 & 0.314 \\
\hline
\end{tabular}

${ }^{1}$ Orthogonal contrasts for comparisons of juniper dietary contibution and total diet: $1=\mathrm{NC}$ vs. C, A, and CSM; $2=\mathrm{C}$ vs. A and CSM; $3=\mathrm{NC}$ and C vs. A and CSM

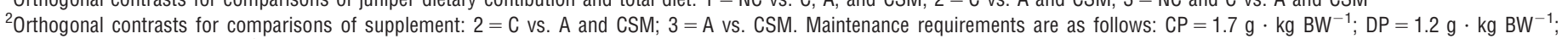
$\mathrm{DE}=0.053 \mathrm{Mcal} \cdot \mathrm{kgBW}^{-1}$ (NRC 1981).

for sheep receiving supplemental protein (Villalba et al. 2002). The increased intake of monoterpene-defended plant following a supplemental protein regime indicates that high protein supplements might aid in the metabolic detoxification of monoterpenes.

Freeland and Janzen (1974) proposed that intake of toxins are limited by detoxification processes. Marsh et al. (2005) conclusively linked detoxification capacity of the monoterpene cineole with feeding behavior in brushtail possums. Oxidation of monoterpenes is catalyzed by cytochrome P450 enzymes (Scheline 1991). Following oxidation, monoterpenes are conjugated with glucuronide and excreted in the urine (Harvey 1942; Wright 1945; Sheline 1991). High-protein diets enhance rates of P450-catalyzed oxidations (Anderson et al. 1982; Guengerich 1984; Guengerich 1995) and therefore potentially can increase the rate of oxidation of monoterpenes. In contrast, chronic high-carbohydrate diets decrease P450 activities, in a pattern contrasting with that seen for protein (Campbell and

Table 4. Mean \pm standard error of percentage juniper in the diet of free-ranging goats as affected by category of juniper intake, breed, and soybean meal supplementation.

\begin{tabular}{lll}
\hline & Mean \pm SE & Probability \\
\hline Category & & \\
High & $29.1 \pm 2.2$ & \\
Low & $22.4 \pm 2.0$ & $P=0.0031$ \\
Breed & & \\
$\quad$ Angora & $27.1 \pm 2.0$ & \\
Boer $\times$ Spanish & $24.5 \pm 2.1$ & \\
Supplementation & & \\
$\quad$ Supplement & & \\
None & $28.1 \pm 2.1$ & \\
\hline
\end{tabular}

Hayes 1974; Parke and Ioannides 1981; Anderson et al. 1982). If the limiting reaction in juniper consumption is detoxification through enzymatic pathways, increasing detoxification capacity through protein supplementation can reduce the bottleneck and increase juniper intake.

The importance of degradable protein (DP) in contrast to total protein on detoxification capacity remains unclear. In our results, as percentage DP in the supplement increased, juniper intake increased. This remains an interesting area for future investigation. It is possible that the effect on microbial fermentation and/or higher levels of microbial protein reaching the abomasum provides a better source of amino acids for incorporation into oxidative enzymes required for increased detoxification capacity. The literature regarding protein supplementation and mixed function oxidase activities (Anderson et al. 1982; Guengerich 1995) describes results from studies done with monogastric animals, and does not take into account the effect of fore-stomach fermentation on the availability of protein substrates.

\section{Energy}

All the supplemental diets in Experiment 1 were isonitrogenous, yet juniper intake was less with corn, a high-starch supplement, than for alfalfa and cottonseed, which both contain a relatively high concentration of protein $(P=0.004)$. In fact there was no difference in juniper intake between the negative control and corn $(P=0.944)$. When the supplements were evaluated for digestible energy content (DE), the lack of a response to the protein in the corn supplement can be explained (Table 4). There was an inverse relationship between DE content and juniper intake. The high starch content of the corn supplement, combined with the fact that it comprised close to $100 \%$ of the goats' diets, might have created conditions favoring amylolytic bacteria to predominate in the rumen. Bacterial fermentation of high starch diets reduces ruminal $\mathrm{pH}$, which halts cellulose 
digestion (Owens and Goetsch 1988). Thus in addition to the potential negative effect of high starch diets on detoxification of monoterpenes, a further reduction in juniper intake might result from decreased digestibility of juniper, which is high in cellulose. Intake and digestion of the fibrous portion of low quality diets are decreased with high intake of energy concentrates (Head 1953; Mertens and Loften 1980).

When comparing DE values of diets with DE requirements (Table 3) it is clear that there is a deficiency in overall energy consumed for the alfalfa and cottonseed meal treatments, but a slight surplus in the corn group. Although it might appear that a hunger effect was the cause of increased juniper intake in these groups when compared to a satiety effect in the corn group, this is not supported by juniper intake in the control group. In fact, there was no difference in intake between the control treatment and the corn treatment, indicating that a negative energy status was not enough of a stimulus to elicit increased juniper consumption.

Monoterpenes have the potential to exacerbate the negative effects of a high starch diet. Oxygenated monoterpenes in sagebrush inhibited cellulolytic bacteria populations in deer (Nagy and Tengerdy 1968). In goats, volatile fatty acid profiles of microbial populations before and after dosing with juniper oil shifted, implying a decrease in cellulolytic in favor of sachharolytic species (Straka et al. 2004). When feed refusals were compared in order to compare gross intake levels, the corn treatment group had the highest level of feed refusal. The most plausible explanation for the decline in feed intake in this study was due to attempts by goats to "correct" imbalances in the ruminal environment through their feeding behavior (Cooper et al. 1996).

\section{Range vs. Pen Experiments}

This study illustrated that supplemental protein increased juniper intake in both a confined feeding and in a free-range situation. In pen studies, choices are limited and the confinement situation might predispose animals to exhibit an exaggerated preference toward target plants due to lack of options for dietary selection. In a pasture environment, when confronted with a diverse array of botanical choices, the effectiveness of protein supplementation on increasing intake of a specific chemically defended plant might be ambiguous. This study showed that despite the removal of choice constraints and subsequent diverse forage availability, supplementation with protein increased juniper consumption by goats maintained in juniper-infested pastures $(30 \%-50 \%$ canopy cover).

\section{Breed and Individual Animal Differences}

The variability in juniper intake among animals $(\mathrm{SE}=2.53)$ plays a greater role in patterns of juniper intake in a population than does the variability between breeds $(\mathrm{SE}=1.27)$. Breed differences that have been reported in the literature support greater levels of intake $\left(\mathrm{g} \cdot \mathrm{kg} \mathrm{BW}^{-1}\right)$ of juniper by larger framed, mixed breeds such as Spanish (Riddle et al. 1996) or Spanish $\times$ Boer goats (Bisson et al. 2001) than in the smaller mohair-producing Angora breed. This indicated that selective breeding for a specific trait (such as mohair production) might be responsible for reducing the genetic diversity because of a higher coefficient of inbreeding or management interventions might remove the selective pressures for animals to develop physiological mechanisms necessary to consume unpalatable plants. In this study, however, breed differences were not apparent.

Variability in juniper intake among individual animals constituted the greatest source of variation in both experiments in this study. Previous research showed substantial differences in intake among animals within breed (Pritz et al. 1997; Riddle et al. 1999; Bisson et al. 2001). Differences in pharmacological sensitivity to monoterpenes could account for idiosyncrasies within populations of goats. Inheritance accounts for a large part of the differences between individuals in the response to an administered drug (Rowland and Tozer 1989). Utilizing intraspecific differences to breed strains that can exhibit fast or slow metabolism for a particular compound (Vesell 1968) has long been suggested as a means to increase capacity of mammals to degrade specific chemicals (Freeland and Janzen 1974). The identification of a bimodal frequency distribution of juniper consumption, where there were significant differences in juniper intake equal to almost one third of total intake identified in the second study, indicates promise for developing a successful breeding program for juniper consumption.

\section{MANAGEMENT IMPLICATIONS}

Numerous studies implicate protein as an important factor in increasing detoxification capacity and subsequently increasing consumption of a chemically defended plant. Providing protein at a rate of $1.5 \mathrm{~g} \cdot \mathrm{kg} \mathrm{BW}^{-1}$ in a high-protein, low-starch supplement can increase juniper intake of goats in a pen environment and on pasture. The nutrient quality of the supplement can affect the availability of molecular substrates for incorporation into metabolic detoxification pathways. Although corn is often fed to goats on range, this practice is detrimental to grazing goats as a low-cost brush management tool. A supplement with lower DE would promote greater juniper intake when juniper management through herbivory is the primary objective.

Three critical elements in managing juniper with goats include 1) reducing the stature of the juniper to within reach of the goats, 2) browsing with a high ratio of goats to juniper, and 3) reducing seedling recruitment by harvesting juniper in the cotyledon stage. The first two elements could involve the integration of other brush management treatments (i.e., mechanical, prescribed fire, etc.). However, regardless of the treatment or combination of treatments used to manage juniper, improving the efficacy of goat use of juniper is an important part of the overall juniper management plan. Increased juniper intake by goats, whether by selection of high-consuming animals or by protein supplementation, reduces use on other more desirable forage species and creates a targeted grazing pressure on the undesirable species. Furthermore, the economic response to supplementation with respect to animal performance is already well established. Huston et al. (1971) concluded that if goats are worth keeping, they are worth supplementing to the level required to maintain health and vigor. The current study was designed to utilize and evaluate typical winter supplementation practices used by ranchers to provide adequate nutritional quality to goats on rangeland during periods of forage dormancy. 


\section{LITERATURE CITED}

Anderson, K. E., A. H. Conney, and A. Kappas. 1982. Nutritional influences on chemical biotransformations in humans. Nutrition Reviews 40:161-171.

Bisson, M. G., C. B. Scott, and C. A. Taylor, JR. 2001. Activated charcoal and experience affect intake of juniper by goats. Journal of Range Managment $54: 274-278$

Bovey, R. W., and C. W. Richardson. 1991. Organic chemicals in the environment. Journal of Environmental Quality 20:528-531.

Bryant, F. C., M. M. Kothmann, and L. B. MerRill. 1979. Diets of sheep, Angora goats, Spanish goats, and White-tailed deer under excellent range conditions. Journal of Range Management 32:412-417.

Burritt, B. A., R. E. Banner, and F. D. Provenza. 2000. Sagebrush ingestion by lambs: effects of experience and macronutrients. Journal of Range Management 53:91-96.

Campbell, T. C., and J. R. Hayes. 1974. Role of nutrition in the drug-metabolizing enzyme system. Pharmacological Reviews 26:171-197.

Cooper, S. D. B., I. Kyriazakis, and J. D. Oldham. 1996. The effects of physical form of feed, carbohydrate source, and inclusion of sodium bicarbonate on the diet selections of sheep. Journal of Animal Science 74:1240-1251.

Dairy ONE. 2006. Feed composition library. Available at: http://www.dairyone.com/ Forage/FeedComp/default.asp. Accessed 6 February 2006.

Freeland, W. J., and D. H. Janzen. 1974. Strategies in herbivory by mammals: the role of plant secondary compounds. American Naturalist 108:269-289.

Guengerich, F. P. 1984. Effects of nutritive factors on metabolic processes involving bioacitvation and detoxication of chemicals. Annual Review of Nutrition 4:207-231.

GuengeRich, F. P. 1995. Influence of nutrients and other dietary materials on cytochrome P-450 enzymes. American Journal of Clinical Nutrition 61:651S-658S.

Harvey, J. M. 1942. The detoxication of terpenes by sheep. Department of Chemistry Paper No. 23. Brisbane, Australia: University of Queensland. $10 \mathrm{p}$.

HEAD, M. J. 1953. The effect of quality and quantity of carbohydrate and protein in the ration of sheep on the digestibility of cellulose and other constituents of the ration, with a note on the effects of adding vitamins of the B-complex on the digestibility and retention of nutrients of a hay ration. Journal of Agricultural Science 43:281-293.

Hester, J. W., T. L. ThuRow, And C. A. TAYLOR, JR. 1997. Hydrological characteristics of vegetation types as affected by prescribed burning. Journal of Range Management 50:199-204.

Hoffmann, R. R. 1973. Evolutionary steps of ecophysiological adaptation and diversification of ruminants: a comparative view of their digestive system. Oecologia 78:443-457.

Huston, J. E., B. S. Rector, L. B. Merrill, and B. S. Engdahl. 1981. Nutritional value of range plants in the Edwards Plateau region of Texas. College Station, TX: Texas Agricultural Experiment Station Publication B-1357. 16 p.

Huston, J. E., M. Shelton, and W. C. Ellis. 1971. Nutritional requirements of the Angora goat. College Station, TX: Texas Agricultural Experiment Station Publication B-1105. $16 \mathrm{p}$.

Johnson, T. N. J. 1980. Picloram in water and soil from a semi-arid Pinyon-Juniper watershed. Journal of Environmental Quality 9:601-605.

Lee, A. C., J. R. Conner, J. W. Muelde, and J. W. Richardson. 2001. Regional cost share necessary for rancher participation in brush control. Journal of Agricultural and Resource Economics 26:478-490.

Marsh, K. J., W. J. Foley, and I. R. Wallis. 2005. Detoxification rates constrain feeding in common brushtail possums (Trichosurus vulpecula). Ecology 86:2946-2954.

Mertens, D. R., and J. R. Lofton. 1980. The effect of starch on forage fiber digestion kinetics in vitro. Journal of Dairy Science 63:1437-1446.

Nagy, J. G., And R. P. Tengerdy. 1968. Antibacterial action of essential oils of Artemisia as an ecological factor. II. Antibacterial action of the volatile oils of Artemisia tridentata (big sagebrush) on bacteria from the rumen of mule deer. Applied Microbiology 16:441-444.

[NRC] National Research Council. 1981. Nutrient requirements of goats. Washington, DC: National Academy Press. 91 p.
Owens, F. N., And A. L. Goetsch. 1988. Ruminal fermentation. In: D. C. Church [ed.] The ruminant animal: Digestive physiology and nutrition. Prospect Heights, IL: Waveland Press. p. 145-171.

Parke, D. V., and C. Ioannides. 1981. The role of nutrition in toxicology. Annual Review of Nutrition 1:207-234.

Pritz, R. K., K. L. Launchbaugh, and C. A. TayloR, JR. 1997. Effects of breed and dietary experience on juniper consumption by goats. Journal of Range Management 50:600-606.

Provenza, F. D., E. A. Burritt, T. P. Clausen, J. P. Bryant, P. B. Reichardt, and R. A. Distel. 1990. Conditioned flavor aversion: a mechanism for goats to avoid condensed tannins in blackbrush. The American Naturalist 136:810-828.

RalphS, M. H., AND F. E. Busby. 1979. Prescribed burning: vegetative change, forage production, cost, and returns on six demonstration burns in Utah. Journal of Range Management 32:267-270.

Riddle, R. R., C. A. Taylor, JR., J. E. Huston, and M. M. Kothmann. 1999. Intake of ashe juniper and live oak by Angora goats. Journal of Range Management $52: 161-165$

Riddle, R. R., C. A. Taylor, JR., M. M. Kothmann, and J. E. Huston. 1996. Volatile oil contents of ashe and redberry juniper and its relationship to preference by Angora and Spanish goats. Journal of Range Management 49: 35-41.

Rowland, M., And T. N. Tozer. 1989. Clinical pharmacokinetics: Concepts and applications. Malvern, PA: Lea \& Febiger. 546 p.

SAS Institute, Inc. 2002. User's Guide, Release 8.03 ed. Cary, NC: SAS Institute. $4420 \mathrm{p}$.

SCHELINE, R. R. 1991. CRC Handbook of mammalian metabolism of plant compounds. Boca Raton, FL: CRC Press. 138 p.

Snowder, G. D., J. W. Walker, K. L. Launchbaugh, and L. D. Van Vleck. 2001. Genetic and phenotypic parameters for dietary selection of mountain big sagebrush (Artemesia tridentata Nutt. ssp. vaseyana [Rydb] Beetle) in Rambouillet sheep. Journal of Animal Science 79:486-492.

Steuter, A. A., And C. M. Britton. 1983. Fire-induced mortality of redberry juniper (Juniperus pinchotii Sudw.). Journal of Range Management 36:343-345.

Straka, E. J., C. B. Scott, C. A. Taylor, and E. M. Balley. 2004. Biological control of the toxic shrub juniper. In: T. Acamovic [ED.]. Poisonous plants and related toxins. Cambridge, MA: CABI Publishing. p. 436-442.

TAYLoR, C. A., JR. 2006. Targeted grazing to manage fire risk. In: K. Launchbaugh and J. Walker [EDS.]. Targeted grazing: A natural approach to vegetation management and livestock enhancement. Englewood, CO: American Sheep Industry Association. p. 108-115.

Taylor, C. A., JR., N. E. GarzA, JR., and T. D. Brooks. 1993. Grazing systems on the Edwards Plateau of Texas: are they worth the trouble? I. Soil and vegetation response. Rangelands 15:53-57.

TayloR, C. A., JR., and M. H. Ralphs. 1992. Reducing livestock losses from poisonous plants through grazing management. Journal of Range Management 45:9-12.

Ueckert, D. N., R. A. Phillips, J. L. Peterson, X. B. Wu, and D. F. Waldron. 2001. Redberry juniper canopy cover dynamics on western Texas rangelands. Journal of Range Management 54:603-610.

UeCKert, D. N., S. G. Whisenant, And R. J. Ansley. 1994. Biology and ecology of redberry juniper. In: C. A. Taylor, Jr. [ED.]. 1994 Juniper Symposium, Sonora, TX. College Station, TX: Texas Agricultural Experiment Station Technical Report 94-2. p. 25-29.

USDA-SCS. 1972. Technical guides, section Ile, range site description, low stony hills range site, PE-19-25. Major land resource areas for the Edwards Plateau. Temple, TX: Texas Soil Conservation Service. $33 p$.

VESELL, E. S. 1968. Factors altering the responsiveness of mice to hexobarbital Pharmacology 1:81-97.

Villalba, J. J., and F. D. Provenza. 2005. Foraging in chemically diverse environments: energy, protein, and alternative foods influence ingestion of plant secondary metabolites by lambs. Journal of Chemical Ecology $31: 123-138$

Villalba, J. J., F. D. Provenza, and R. E. Banner. 2002. Influence of macronutrients and activated charcoal on intake of sagebrush by sheep and goats. Journal of Animal Science 80:2099-2109. 
Walker, J. W., E. S. Campbell, C. J. Lupton, C. A. Taylor, JR., D. F. Waldron, and S. Y. LANDAu. 2007. Contribution of breed, gender, and age to variation and predictive ability of near-infrared reflectance spectra of goat feces. Journal of Animal Science 85:518-526.

Warren, L., D. UeCKert, and M. Shelton. 1981. Dietary choices of selected breeds of sheep and goats grazing in west Texas. Texas Agricultural Experiment Station Progress Report 3907:84-91.

Warren, L. E., D. N. UeCKert, and J. M. Shelton. 1984. Comparative diets of Rambouillet, Barbado, and Karakul sheep and Spanish and Angora goats. Journal of Range Management 37:172-180.
Whitson, R. E., L. B. Merrill, H. T. Wiedemann, and C. A. Taylor, Jr. 1984. Economic feasibility of brush control in the Edwards Plateau. Miscellaneous publication MP-1554. College Station, TX: Texas Agricultural Experiment Station. $8 p$.

WHitworTH, W. R. 2002. Estimating redberry and ashe juniper intake using fecal NIRS [thesis]. San Angelo, TX: Angelo State University. 46 p.

Wright, H. A., F. M. Churchill, and W. C. Stevens. 1976. Effect of prescribed burning on sediment, water yield, and water quality from dozed juniper lands in central Texas. Journal of Range Management 29:294-298.

WRIGHT, S. E. 1945. Detoxication mechanisms in sheep. Department of Chemistry Paper No. 25. Brisbane, Australia: University of Queensland. $10 \mathrm{p}$. 